\title{
GRAY FOX AND COYOTE ABUNDANCE AND DIET RESPONSES AFTER A WILDFIRE IN CENTRAL ARIZONA
}

\author{
Stan C. Cunningham ${ }^{1}$, LariBeth Kirkendall ${ }^{1}$, and Warren Ballard ${ }^{2}$
}

\begin{abstract}
There is a paucity of information on the effects of wildfire on carnivores. We studied the effects of a 237$\mathrm{km}^{2}$ catastrophic wildfire in the Mazatzal Mountains, Arizona, on gray foxes (Urocyon cinereoargenteus) and coyotes (Canis latrans). We indexed relative abundance 3 times each year from 1996 tol998 using scat transects in burned and unburned areas. We collected scats to estimate diet and measured small mammal abundance and mast availability in 1997 and 1998. We also measured vegetation cover in burned and unburned sites. Gray fox indices declined 3 months postfire, but after 30 months, indices returned to preburn levels. Coyote indices did not change. Primary foods for both species in burned and unburned sites were mast (fruits of shrubs) and rodents, and diet comparisons between sites became similar as plant succession continued. Scat indices did not correlate with seasonal small mammal abundance. We suspect that the lower abundance indices of gray foxes were related to reduction in cover and food availability, because indices increased as vertical cover and mast crop increased. These data indicate that the effects of this catastrophic fire were short-term but also highlight the importance of preserving shrub and vegetation diversity for gray fox.
\end{abstract}

Key words: gray fox, coyote, fire, Arizona, scat index, diet, Madrean evergreen forest, chaparral, sky island.

Baisan and Swetnam (1990) characterized fire history on Arizona mountain ranges from 1697 to 1860 as large scale (>200 ha), early season (May-July) surface fires averaging every 6 years. This frequent fire regime ensued from an annual cycle of a wet winter (NovemberFebruary), a normally arid foresummer (AprilJune), and a period of isolated dry lightning storms before the onset of summer monsoonal rains (July-September). Fire frequency in the southwest diminished from 1870 to present because of changes in land use, fire suppression, and removal of fine fuels by excessive livestock grazing (Swetnam and Betancourt 1990). With fire exclusion, dead fuels accumulated and dense thickets formed in interior chaparral and invaded open ponderosa pine (Pinus ponderosa) stands, increasing the risk of crown scorching or "catastrophic" fires (Fule and Covington 1994). These stand-replacing fires probably have not existed for many centuries, yet constantly accumulating fuels have no other means of elimination (Fule and Covington 1994).

On 28 April 1996 campers started the Lone Fire on Four Peaks in the Mazatzal Mountains, Arizona, and $237 \mathrm{~km}^{2}$ burned in 16 days. Greater than $90 \%$ of the vegetation was either completely denuded or killed on the sky island, which is defined as a forest patch (island) surrounded by chaparral and desert at lower elevations. High vegetation mortality is "ecologically unnatural” because historically frequent fire regimes allowed mountaintop forests to burn without mature tree mortality and complete destruction of cover (Fule and Covington 1994).

Although the effect of wildfires on some ungulates is well studied, the effects of fire on mesocarnivores are difficult to predict. Increased densities of badgers (Taxidea taxis), bobcats (Lynx rufus), and coyotes (Canis latrans) following fire in the Rocky Mountains, USA, were associated with increased prey availability due to loss of hiding cover (Lawrence 1966, Gruell 1980, Patton and Gordon 1995). OgenOdoi and Dilworth (1984) determined that hare (Lepus spp.) populations increased 3 months after a prescribed burn in savanna grassland in East Africa, but predator numbers were not affected. In contrast Rabinowitz (1990) found annual fires in Thailand decreased numbers of leopard cats (Felis bengalensis) by destroying rodent habitat. Poole et al. (1996) found that good snowshoe hare (Lepus americamus) habitat, and hence good lynx (Lynx canadensis) habitat, initially deteriorated postfire in the Northwest

${ }^{1}$ Research Branch, Arizona Game and Fish Department, 2221 W. Greenway Road, Phoenix, AZ 85023.

${ }^{2}$ Department of Range, Wildlife, and Fisheries Management, Texas Tech University, Box 42125, Lubbock, TX 79409. 
Territories, Canada, but improved after 20 years with increased vegetative diversity in later successional stages.

Because catastrophic fires are ecologically recent in the southwest and the effects of fire on carnivores are not well understood, we examined the effects of the Lone Fire on gray foxes (Urocyon cinereoargenteus) and coyotes. Our objective was to document any postfire changes in population scat indices of gray fox and coyote. Since predator number changes may be linked to food availability, we examined diets of the 2 carnivores in burned and unburned vegetation. We also measured small mammal abundance and the phenological state of key mast species to determine if correlations existed between carnivore indices and primary food items. We predicted the loss of vegetation could be detrimental, so we measured vertical cover of vegetation at the end of each year's growing season in burned and unburned areas.

\section{Study Area}

The $1008-\mathrm{km}^{2}$ study area was $80 \mathrm{~km}$ northeast of Phoenix, Arizona, in the southern Mazatzal Mountains (Fig. 1). The 2 prominent landmarks in the study area included a burned sky island, Four Peaks, and an unburned one, Mt. Ord. Elevations ranged from $720 \mathrm{~m}$ to $2300 \mathrm{~m}$, with steep, rocky topography and many slopes $>45 \%$. Annual precipitation at Roosevelt, Arizona (elevation $720 \mathrm{~m}$ ), on the eastern edge of the study area, averaged $63 \mathrm{~cm}$ including occasional snows that usually melted within a week. Average temperatures (1903-2000) ranged from $39^{\circ} \mathrm{C}$ in July to $15^{\circ} \mathrm{C}$ in December (NOAA 2000). The Mazatzal Mountains have a precipitation gradient of $1 \mathrm{~cm}$ per $300 \mathrm{~m}$ and a temperature gradient of $1^{\circ} \mathrm{C}$ per 100 -m change in elevation (Sellers and Hill 1974).

Primary vegetative type was interior chaparral (900-1850 m; Brown and Lowe 1974), a complex association of shrubs and short $(<2$ m) trees that integrated with Arizona upland desert scrub and semi-desert grassland at lower elevations $(<900 \mathrm{~m})$. At the higher elevations $(>1850 \mathrm{~m})$ on Four Peaks and Mount Ord, Madrean evergreen woodland (ponderosa pine, Gamble's oak [Quercus gambelli], and Emory oak [Quercus emoryi] interspersed with a large number of chaparral species) and a block of homogeneous ponderosa pine forest existed.
Major drainages were composed of riparian communities consisting of both deciduous and evergreen forest types.

Within burned sites, most cover (vegetation that could shelter a coyote or gray fox) was initially destroyed. The trunks and large branches of trees and most shrub species were charred but intact. Initially there were no leaves on charred branches, but most species, excluding ponderosa pine, regenerated at the base. Within the burn perimeter 2 patches of unburned vegetation $\left(16 \mathrm{~km}^{2}\right.$ and $\left.10.8 \mathrm{~km}^{2}\right)$ remained.

\section{Materials and Methods}

\section{Carnivore Abundance}

We indexed gray fox and coyote abundance on 19 scat transects in burned sites and 25 transects in unburned chaparral and forest (Fig. 1). Clark (1972), Weaver (1977), Hoffman (1979), Davison (1980), Stoddart (1984), and Cunningham et al. (2001) all used scat deposition rates to index carnivore populations in their respective study areas. Scat deposition rates were highly correlated $\left(r^{2}=0.97\right)$ with 4 estimates of coyote density derived from markrecapture experiments involving radioactive tagging of feces (Pelton and Marcum 1975, Davison 1980), suggesting this technique might be quite sensitive to changes in coyote abundance. However, Knowlton (F.F. Knowlton, Denver Wildlife Research Center, USDA APHIS, unpublished report) suggested possible biases associated with scat transects: (1) removal of scats from transects might slightly reduce the number of scats deposited in subsequent days (i.e., old scats motivate deposition of new scats); (2) interobserver reliability is relatively low; and (3) scat persistence is inversely related to amount of vehicular traffic. The most important bias involves failure to detect scats while walking transects.

We cleared all carnivore scats by walking transects 2 times, once in each direction, to partially avoid the failure to detect scats. All permanent scat transects were $\geq 1 \mathrm{~km}$ in length and located only on unmaintained roads or hiking trails to reduce the effect of vehicular traffic on scat deposition. Ten to 21 days later, we again walked each transect twice, counting and collecting scats along the way. We calculated the abundance index for each species as the number of scats divided by the number of nights of scat accumulation times 100 per $\mathrm{km}$ 


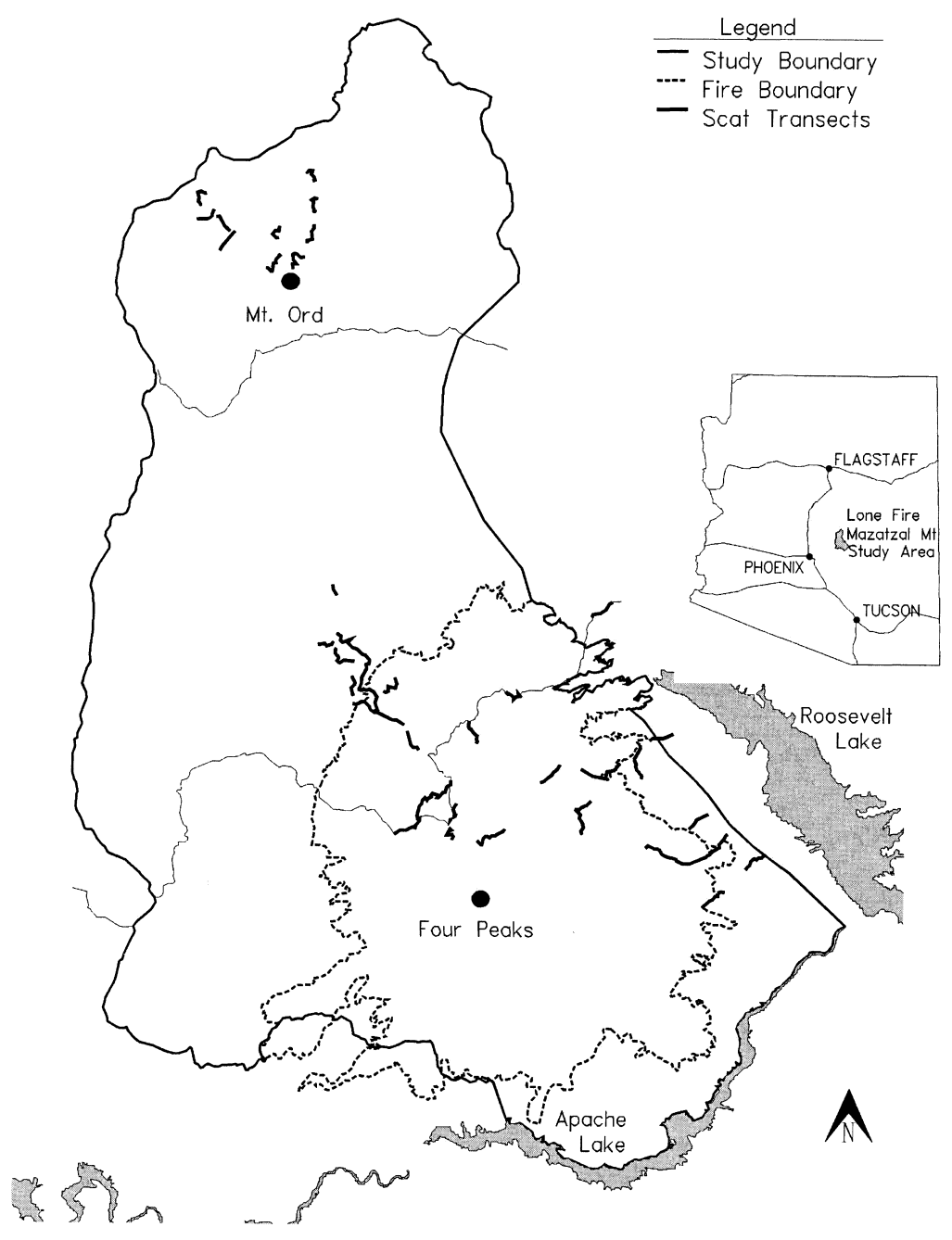

Fig. 1. Map of the study area in the Mazatzal Mountains, Arizona, 1996-1999, including the Lone Fire boundary, Four Peaks and Mt. Ord sky islands, and locations of each predator scat transect.

(F.F. Knowlton, Denver Wildlife Research Center, USDA APHIS, unpublished report). We used visual characteristics (size, shape, and width) of Murie (1954) and Danner and Dodd (1982) to identify scats. Because interobserver variability can increase bias, all scats were visually identified only by the senior author (S.C. Cunningham). Recent studies suggest that experience and training are major factors in achieving accurate visual identifications of carnivore feces (Zuercher et al. 2003).

We sampled $19.5 \mathrm{~km}$ and $27.2 \mathrm{~km}$ of scat transects in burned and unburned sites, respectively. To determine the maximum area sampled, we created a $3.3-\mathrm{km}$ buffer around all transects and determined the amount of burned $\left(247 \mathrm{~km}^{2}\right)$ and unburned vegetation $\left(758 \mathrm{~km}^{2}\right)$ from which carnivores could be sampled. We sampled in 3 seasonal periods: breeding (February-April), whelping and weaning (MayAugust), and juvenile dispersal (SeptemberNovember). Sampling began in March 1996, just before the Lone Fire, and ended in October 1998. We analyzed scat survey data among years but within the same season due to possible seasonal differences in defecation rates (Andelt and Andelt 1984). Possible differences among years within the same season were determined by ANOVA and a Tukey's multiple comparison test $(\alpha=0.05)$. We also examined graphical 
representations of the data showing the mean \pm standard error and the minimum estimable difference (Johnson 1999). We determined the minimum estimable difference for each species $(\beta=0.9, \alpha=0.05)$ from prefire data collected in March 1996 (Zar 1984).

\section{Carnivore Diet}

We collected gray fox $(n=690)$ and coyote $(n=165)$ scats found on scat transects and used them to estimate diet. Since scats were collected on previously cleared areas, we knew when scats were deposited within 10-21 days. Even though scat transect indices were not calculated in 1999, we continued to collect scats in areas during known time intervals (within 45 days). Scat contents were dried, washed through a series of sieves, examined against a white background through a stereoscope, and separated by food type. We used seed and hair reference collections and hair descriptions from Moore et al. (1974) to identify scat contents. Food items were reported as frequency of occurrence (percent occurrence in the scats) by year for burned and unburned sites.

\section{Small Mammal Abundance}

We sampled small mammals in burned $(n$ $=11$ trapping grids) and unburned $(n=11$ trapping grids) sites on Four Peaks and unburned sites on Mt. Ord ( $n=5$ trapping grids) from June 1997 to October 1998 in the same periods that we ran scat transects. We were not able to sample small mammals in 1996 . We reported abundance as the number of traps containing small mammals divided by trapnights with a minimum of 240 trap-nights per season. Each season we established a $10 \times 40$-m grid ( $n=40$ stations) at random sites located by a global positioning system. We set a $7.5 \times$ $7.5 \times 22.5-\mathrm{cm}$ Sherman live trap (H.B. Sherman Traps, Tallahassee, Florida) at each station and a similarly sized wire live-trap at every other station for a minimum of 4 nights. We baited each trap with a mixture of rolled oats and commercial birdseed, and identified each captured animal to species (Burt and Grossenheider 1980). Each small mammal was marked by ear notches, and we counted only the unique individuals captured in each sampling session, not the total captures. We used linear regression to model associations between scat indices and small mammal abundance for each season.

\section{Vegetation Cover}

At random GPS locations within burned and unburned sites (forest and chaparral; $n>70$ per year) we used 25-m, line-intercept vegetation transects oriented to the landscape contour to sample live vegetative cover in September 1997-1999 at distinct height intervals: 0-0.15 m, 0.16-0.30 m, 0.31-0.90 m, 0.91-1.8 $\mathrm{m}, 1.9-4.6 \mathrm{~m}$, and $>4.6 \mathrm{~m}$. We also recorded the phenological condition, as described by West and Wein (1971), of key mast producing species including manzanita (Arctostaphylos pungens), oaks (4 Quercus spp.), juniper (2 Juniperus spp.), and prickly pear (Opuntia engelmannii) within $10 \mathrm{~m}$ of each random point.

We considered ground cover as vegetation $0-0.3 \mathrm{~m}$ tall and thermal cover as vegetation $>0.9 \mathrm{~m}$. Since gray fox stand between $36 \mathrm{~cm}$ and $38 \mathrm{~cm}$ tall, and coyotes from $58 \mathrm{~cm}$ to 66 $\mathrm{cm}$ (Whitaker 1997), we classified vegetation $0-0.9 \mathrm{~m}$ in height as hiding cover.

\section{REsUlTS}

\section{Carnivore Abundance}

Gray fox scat indices declined postfire (Fig. 2a), and spring values in 1997 were significantly lower than prefire spring levels in 1996 $(F=3.3, P=0.05)$. Gray fox indices in unburned sites were significantly higher $(F=4.8$, $P=0.01)$ in the spring seasons in 1996 than 1998, but 1997 was similar. Graphical depiction of the mean and standard errors (Fig. 2a) showed that gray fox indices were significantly lower in burned sites in fall 1996 and spring 1997, falling below the minimum estimable difference ( $>69 \%$ decline). Gray fox indices in burned sites were highest in 1998 and were higher than indices in unburned vegetation. There were no differences among years in burned $(P$-values $=0.06$ and 0.14$)$ or unburned sites $(P$-values $=0.2$ and 0.6$)$ in the summer or fall seasons.

Coyote scat indices were similar within and between burned and unburned vegetation, and were always lower than gray fox indices. Postfire coyote indices were not significantly less than preburn conditions in the spring $(P$ $=0.3)$, summer $(P=0.4)$, or fall $(P=0.5)$ in burned sites, and always were below the minimum estimable difference (Fig. 2b). In unburned sites, values for spring $(P=0.07)$, summer $(P=0.5)$, and fall $(P=0.9)$ were also similar. Coyote scat indices within the burn 

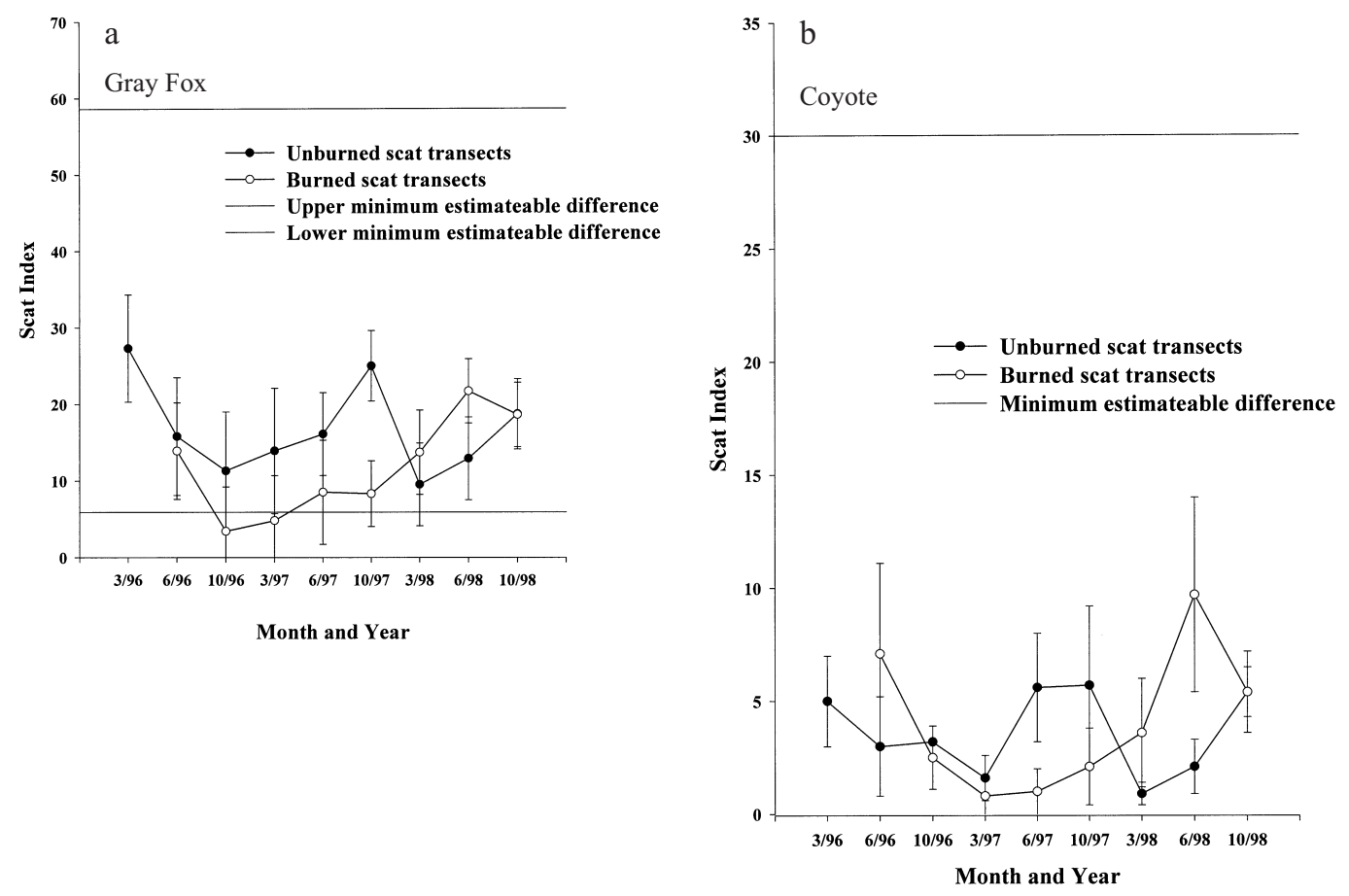

Fig. 2. Gray fox scat indices (a) and coyote scat indices (b) determined in burned and unburned chaparral and forest on Four Peaks and Mt. Ord in the Mazatzal Mountains, Arizona, 1996-1998. Each axis is scaled differently. Note that the fire occurred between the March 1996 and June 1996 samples.

perimeter, measured in June 1996 (immediately following the Lone Fire), were $25 \%$ greater than preburn indices.

\section{Carnivore Diet}

The primary food of gray fox was soft mast (fruit and berries) in all collection periods except at unburned sites in 1999. Rodents, insects, and rabbits were also common (Table 1). The most common fruits consumed were mazanita, one-seed juniper (Juniperus monosperma), serviceberry (Amelianchier bakerii), and prickly pear cactus. Consumption of rodents and rabbits (6.5\%-33.8\%) was similar from 1996 to 1998, both within and outside the burn. In 1999 rodent remains were found in $62.8 \%$ of gray fox scat collected outside the burn, but in only $27.3 \%$ of scats collected in the burn. We found 7 items in scats collected in burned sites in 1996 compared to 19 in unburned sites.

Primary coyote foods in unburned areas were soft mast (mostly manzanita and juniper berries), rodents, and rabbits (Table 2). Within burned sites primary coyote foods were rodents and soft mast (also manzanita and juniper). No rabbit remains were found in coyote scats collected in burned or unburned sites in 1999, a year in which rodents increased to $>75 \%$ of coyote diets. Large mammals (deer, Odocoileus sp.; javelina, Pecari tajacu; and cattle) were consumed more in unburned areas.

\section{Food Abundance}

Small mammal abundance did not differ among seasons or between burned and unburned sites. Within burned areas, small mammal abundance averaged 0.05 individuals captured per trap night and ranged from 0.041 to 0.097. In unburned sites, small mammal abundance averaged 0.047 individuals captured per trap night and ranged from 0.02 to 0.1 . We found no correlations between each species' scat indices and small mammal abundance in 5 seasons among burned and unburned sites from June 1997 to October 1998 (all $r^{2}$ values were $<0.3$ and $P$-values were $>0.1)$.

With respect to key mast species, a greater percentage of plants produced fruit in unburned sites than burned sites in 1997 (85.3\% vs. $23.8 \%$, respectively) and 1998 (91.9\% vs. 62.3\%). 


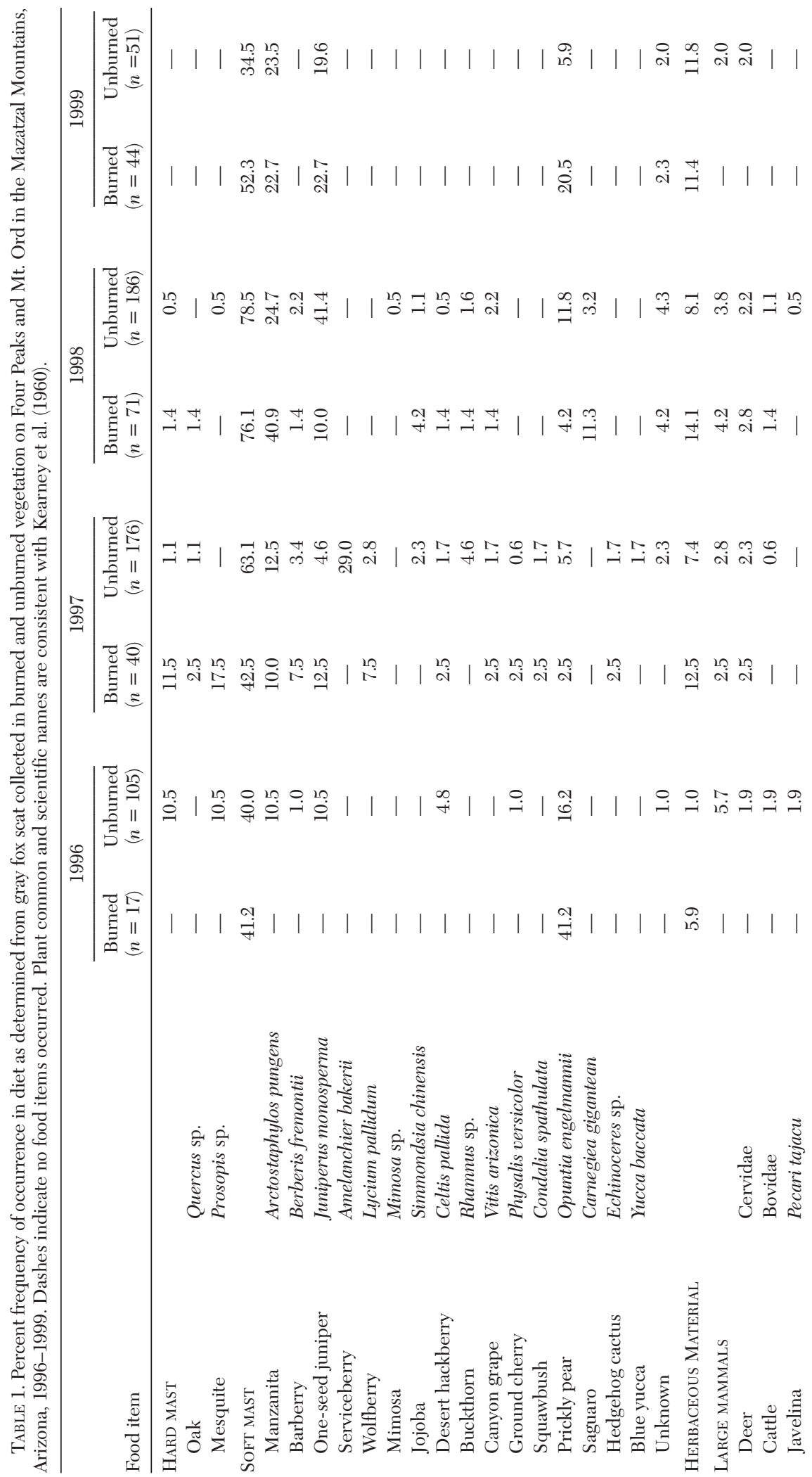




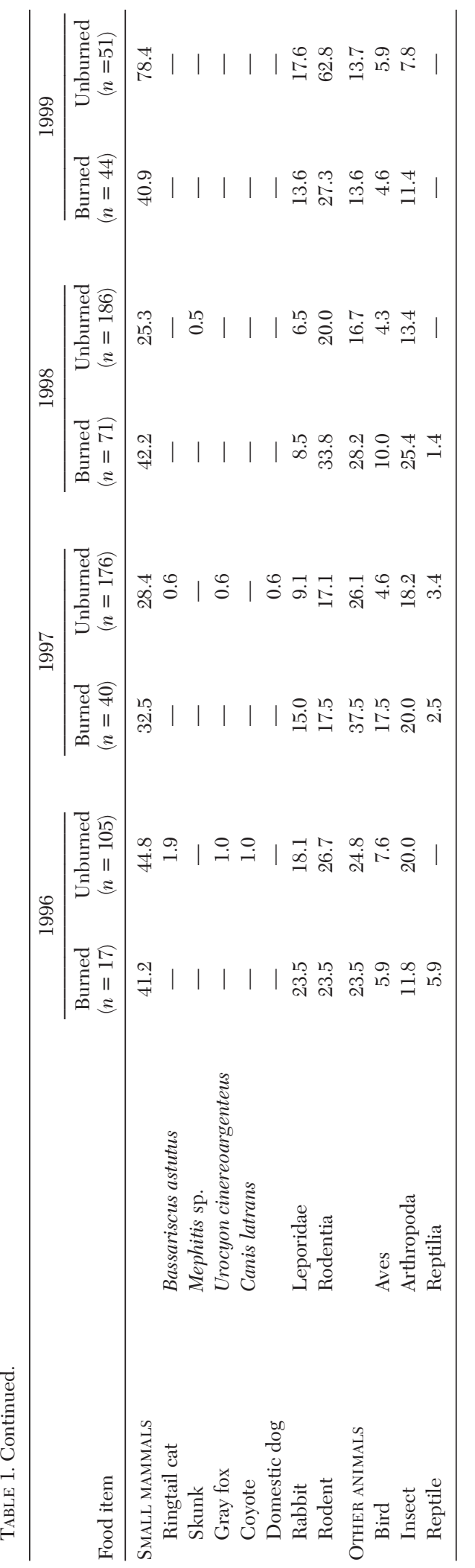

Although not quantified, no burned shrubs were observed producing fruit in 1996. Mast production in burned and unburned sites was equal in 1999 with $65 \%$ of plants producing fruit.

\section{Vegetation Cover}

After 16 months (1997), vegetation ground cover and hiding cover were just over $10 \%$ in burned sites (Fig. 3), approximately 50\% less than in unburned sites. Hiding cover remained less in burned sites than unburned sites in 1998. By September 1999 (40 months postfire), ground cover in burned sites was similar to unburned sites $(>30 \%)$, and hiding cover was close to $30 \%$ in burned sites. Thermal cover was much less in burned than unburned sites in all years.

\section{Discussion}

\section{Carnivore Abundance}

The decline of gray fox after 6 months contrasts results of Patton and Gordon (1995), Gruell (1980), and Lawrence (1966) who found that midsized carnivores increased in abundance after fires. None of the above studies attempted to monitor carnivore numbers for $>6$ months. We believe the decline of gray fox during the postfire year resulted from the loss of $>90 \%$ of the vegetation. Effects on the vegetation were not described in the above studies.

A significant difference between spring indices in unburned sites from 1996 to 1998 was unexpected and not easily explained. There were no habitat changes, nor was the same decline seen in burned sites. It is possible that one of the biases of scat indices listed earlier could have influenced our results. However, because the decline and increase in burned sites seemed to follow obvious treatment changes, we have confidence that fire caused gray fox to decline.

We also monitored the movements and mortalities of a small number of radiocollared carnivores in the burn area following the fire: fox $(n=4)$, bobcats $(n=2)$, and coyote $(n=1)$. Although sample size was small, these data also indicated a decline in carnivore numbers (unpublished data). Four transmittered gray fox living within the burn perimeter survived the fire, and within 2 weeks they moved longer distances than 4 transmittered fox in unburned areas and were only found in unburned riparian corridors. All 4 gray fox stayed within the burn 


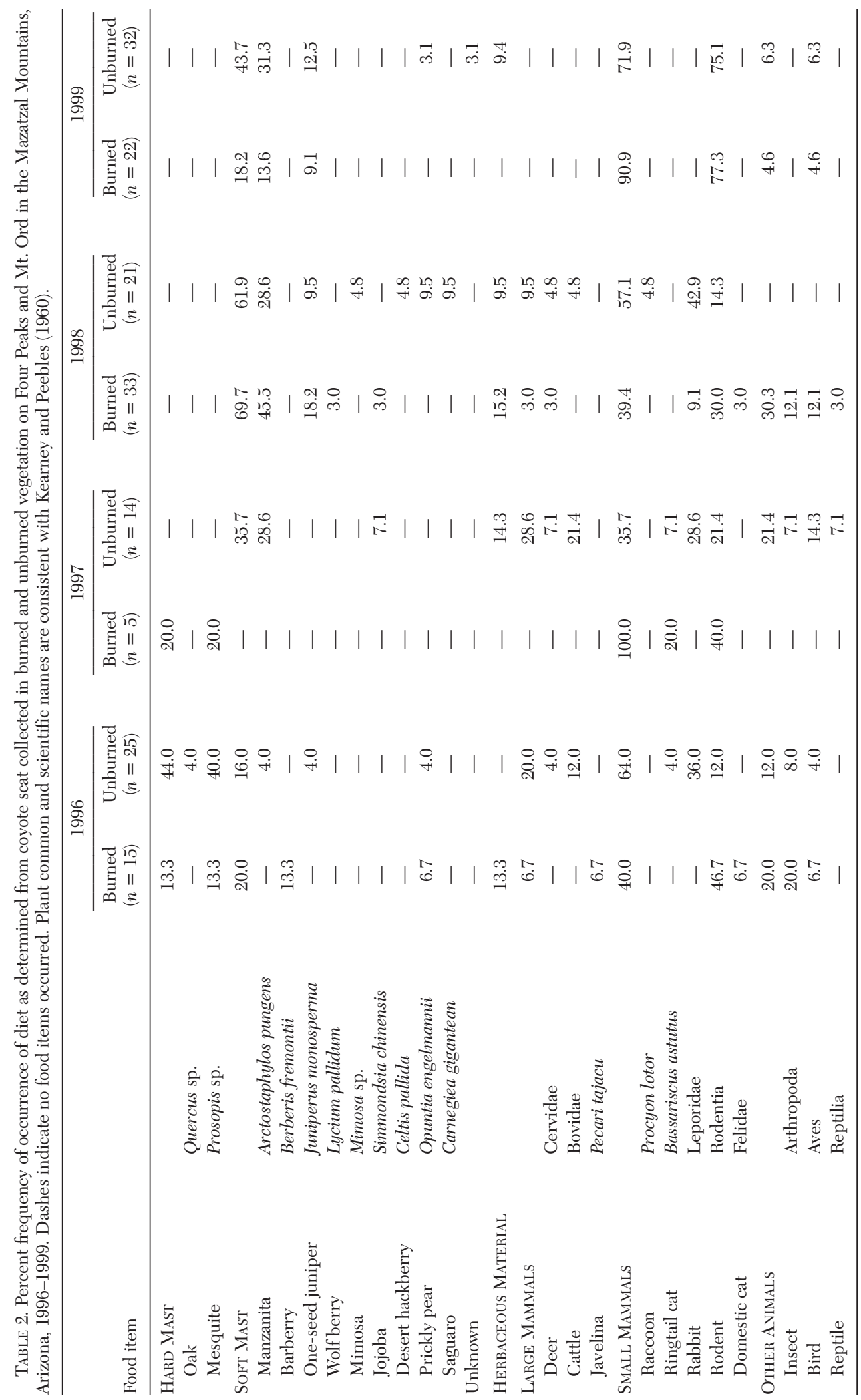




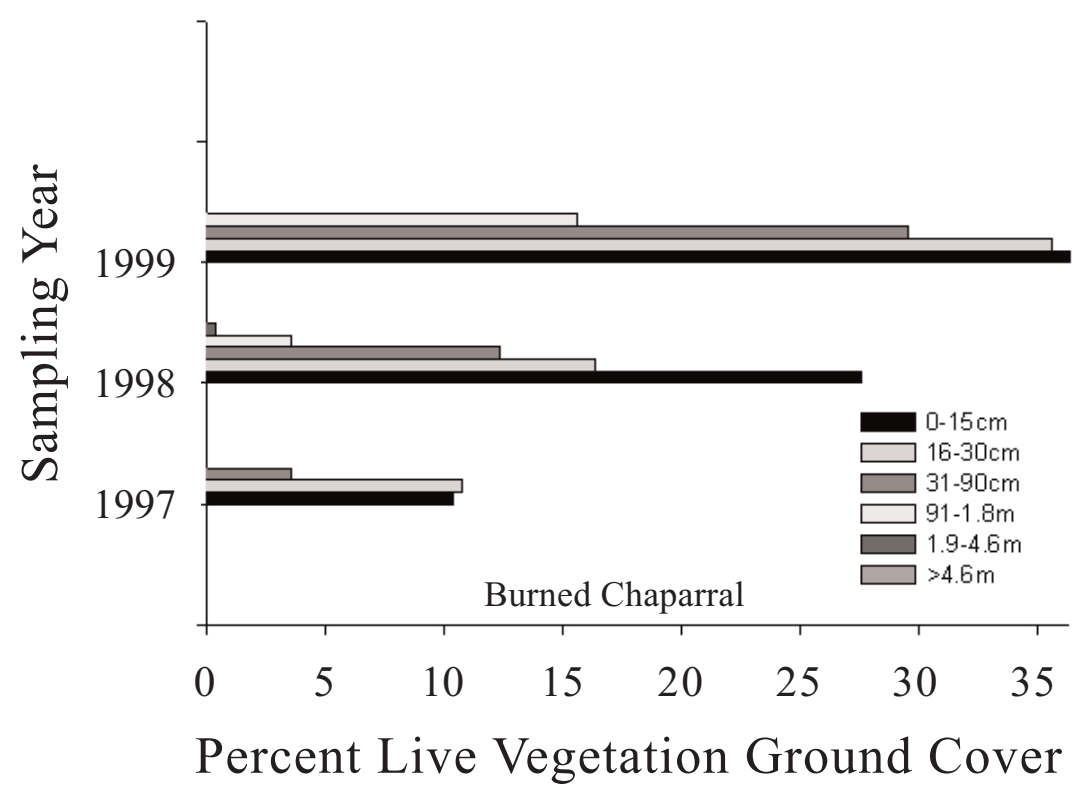

Fig. 3. Percent canopy cover of vegetation by height interval in sites that burned in 1996 and unburned sites measured in September 1997-1999 in the Four Peaks area on the Mazatzal Mountains, Arizona.

perimeter, but died within 2 months, presumably from starvation. The transmittered coyote within the burn perimeter moved to unburned vegetation outside the perimeter and only returned sporadically as vegetation resprouted. Both transmittered bobcats moved out of the burn perimeter after 3 weeks and did not move back during 6 more months of monitoring.

Our data did not indicate that fire gave coyotes an advantage over gray fox or that coyotes caused gray fox to decline. Major and Sherburne (1988) and Theberge and Wedeles (1989) found that red fox (Vulpes vulpes) spatially avoided coyotes; Major and Sherburne (1988) also reported that coyotes consumed fox in western Maine. Although gray fox indices declined as coyotes increased in the 1st postburn sample, after 6 months postfire both species had similar patterns for the next 2 years. We did not document any predation on gray fox or find evidence of such in coyote scats. Gray fox indices also increased in burned sites at the same time coyote indices were highest (1998).

\section{Carnivore Diet}

Gray fox diets vary among temperate zone locations and seasons, and fox are considered more omnivorous than other canids (Fritzell 1987). Other studies report similar diets, with vertebrates more important in winter and insects and plant material more important in summer and fall (Wood et al. 1958, Fritzell 1987, Navaro et al. 1995). However, 2 studies of gray fox diets in the Southwest found a higher consumption of animal matter. In the Sonoran Desert, Arizona, Turkowski (1969) found that mammals and arthropods occurred twice as frequently as plants in gray fox diets. And in Texas Wood (1954) found that cottontails (Sylvilagus spp.) comprised $69 \%$ of gray fox diets and plant material only $11 \%$. In our study, gray fox density within the burn perimeter increased in 1998 when diets consisted primarily of soft mast.

Like gray fox, coyotes ate more mast in unburned than burned sites during breeding. Similarly, Barrett (1982) found that coyotes in a California chaparral community ate soft mast, primarily manzanita, most often in summer and fall. The use of large mammals was greatest in fall and winter (post-fawning) in both vegetation types and was similar to other coyote diet studies (MacCracken and Hansen 1987, Gese et al. 1988, Toweill and Anthony 1988). Interestingly, coyote use of deer did not increase in the burn, even though mule deer preferred feeding on vegetation in the burn (Boyd 2001). We concur with Andelt et al. (1987) that coyotes are opportunistic predators, whose diets 
reflect climatic patterns, vulnerability of prey, effects of plant phenology, and postfire vegetation changes.

\section{Food Abundance}

The Lone Fire reduced mast availability from 1996 through 1998. Mast use increased in the burn area from 1996 to 1998 but was lower in 1999 when fewer shrub species produced. Prickly pear, the only mast species eaten by gray fox in burned sites in 1996, was slow to return after the fire (Boyd 2001). Manzanita did not appear in gray fox diets in the burned area until 1997 or in coyote diets until 1998. Manzanita and prickly pear, though common in chaparral communities, are considered fire intolerant (Patton and Gordon 1995). They do not commonly resprout and recolonize from unburned seed sources in the soil or from animal dung.

Although scat indices were not correlated with small mammal abundance in 1997 and 1998, we still suspect that observed decreases and increases in gray fox and coyote scat indices partially reflected changes in food availability. That carnivore density and home range size are linked to food availability is well documented (Beasom and Moore 1977, Gese et al. 1988, Mills and Knowlton 1991). Mast was a common dietary item for both species; but, even though we had data on the proportion of shrubs producing fruit, we did not estimate availability. Consequently, we could have easily missed a correlation between scat indices and mast production. Small mammal availability was also more than $50 \%$ less than what Jones and Smith (1979) found in a more mesic period (mid-1970s) in the same study area; this could have caused a dietary shift.

Our finding of similar small mammal use by gray fox and coyotes contrasts with reports that gray fox are less carnivorous when sympatric with coyotes or bobcats (Scott 1955, Hockman and Chapman 1983, Major and Sherburne 1988). These reports inferred that spatial segregation and possible food competition was responsible. Gray fox consumed rabbits in burned sites while coyotes did not, indicating coyote presence did not decrease gray fox meat consumption.

\section{Vegetation cover}

Within the $237-\mathrm{km}^{2}$ burn perimeter, there was only $26.8 \mathrm{~km}^{2}$ of unburned vegetation islands in which moderately sized carnivores could find hiding or thermal shelter until 1998. Black bear (Ursus americanus) fire survivors were restricted to these areas during daytime hours, and density estimates within the islands were 3 times the prefire estimates (Cunningham et al. 2003). We suspect that gray fox and coyotes have the same needs for thermal cover and hiding cover both to hunt and avoid predation.

\section{Conclusion}

Our research suggested that catastrophic fires leaving few unburned patches of vegetation can cause a temporary decline in midsized carnivores. However, these effects are relatively short-term. In 4 years postfire we did not note any ponderosa pine reproduction; the forest may not be able to fully recover from this type of fire (Swetnam et al. 1999). Although both carnivores we studied are habitat generalists, the long-term effects of the reduction in ponderosa pine sky-island habitats will not be known for many years. Thermal cover, mast, and small mammal numbers could continue to be affected.

Because high tree density and fuel accumulation increase crown fire danger, greater awareness and commitment to restore conditions to presettlement (pre-1870) tree density have become primary conservation goals in southwestern forests (Allen et al. 2002). New federal guidelines (Federal Register 2002) outlining the importance of clearing brush in forests to reduce fire danger and requesting categorical exclusion from the NEPA process for southwestern forest thinning projects have been introduced. Our data indicate that (1) a density of 40 trees $\cdot$ ha $^{-1}$ with little understory could reduce mesocarnivore density and (2) maintenance of patches of brush and vegetation diversity in areas of forest restoration (thinning) may be necessary. More research is needed to determine the adequate patch sizes of brush and dense vegetation needed to maintain midsized carnivore populations.

\section{ACKNOWLEDGMENTS}

Funding was provided by the Federal Aid to Wildlife Restoration Act Project W78R (Pittman-Robertson). Many individuals from the Arizona Game and Fish Department and volunteers helped with data collection. The authors 
wish to thank C. Ticer, L. Monroe, J. deVos, T. McKinney, N. Dodd, and anonymous reviewers for improving earlier versions of this manuscript.

\section{Literature Cited}

Allen, C.D., M. SaVage, D.A. Falk, K.F. Suckling, T.W. Swetnam, T. Schulke, P.B. Stacey, ET AL. 2002. Ecological restoration of southwestern ponderosa pine ecosystems: a broad perspective. Ecological Applications 12:1418-1433.

AndeLt, W.F., AND S.H. Andelt. 1984. Diet bias in scat deposition rate surveys of coyote density. Wildlife Society Bulletin 12:74-77.

Andelt, W.F., J.G. Kie, F.F. KNOWLton, AND K.CARDwELL. 1987. Variation in coyote diets associated with season and successional changes in vegetation. Journal of Wildlife Management 51:273-277.

BAISAN, C.H., AND T.W. SWETNAM. 1990. Fire history on a desert mountain range: Rincon Mountain Wilderness, Arizona, USA. Canadian Journal of Forest Restoration 20:1559-1569.

BARRETT, R.H. 1982. Food habits of coyotes, Canis latrans, in eastern Tehama County, California. California Fish and Game Quarterly 69:184-192.

Beasom, S.L., AND R.A. Moore. 1977. Bobcat food habit response to a change in prey abundance. Southwestern Naturalist 21:451-457.

Boyd, H.M. 2001. Habitat use of desert mule deer and collared peccaries following a wildfire. Master's thesis, University of Arizona, Tucson.

Brown, D.E., AND C.H. Lowe. 1974. A digitized computercompatible classification for natural and potential vegetation in the southwest with particular reference to Arizona. Journal of Arizona Academy of Science 9 (Supplement 2).

Burt, W.H., AND R.P. Grossenheider. 1980. A field guide to the mammals: North America north of Mexico. Houghton Mifflin Company, New York.

ClaRK, F.W. 1972. Influence of jackrabbit density on coyote population change. Journal of Wildlife Management 36:343-356.

Cunningham, S.C., L.M. Monroe, L. Kirkendall, and C.L. TICER. 2001. Effects of the catastrophic Lone Fire on low, medium, and high mobility wildlife species. Technical Guidance Bulletin No. 5, Phoenix, AZ.

Danner, D.A., And N.L. DodD. 1982. Comparisons of coyote and gray fox scat diameters. Journal of Wildlife Management 46:240-241.

DaVison, R.P. 1980. The effect of exploitation on some parameters of coyote populations. Doctoral dissertation, Utah State University, Logan.

Federal Register. 2002. National forest system land and resources management planning. USDA Forest Service. 6 December 2002. Federal Register 67(235): 72769-72816. Available from: www.gpoaccess.gov/fr/.

FritzelL, E.K. 1987. Gray fox and island gray fox. In: M. Novak, J.A. Baker, M.E. Obbard, and B. Malloch, editors, Wild furbearer management and conservation in North America. Ontario Ministry of Natural Resources, Toronto, Canada.

Fule, P.Z., AND W.W. Covington. 1994. Fire-regime disruption and pine-oak forest structure in the Sierra
Madre Occidental, Durango, Mexico. Restoration Ecology 2:261-272.

Gese, E.M., O.J. Rongstad, and W.R. Mytton. 1988. Relationship between coyote group size and diet in southeastern Colorado. Journal of Wildlife Management 52:647-653.

GruELL, G.E. 1980. Fire's influence on wildlife habitat on the Bridger-Teton National Forest. USDA Forest Service Research Report, Ogden, UT.

Hockman, J.G., And J.A. Chapman. 1983. Comparative feeding habits of red foxes (Vulpes vulpes) and gray foxes (Urocyon cinereoargenteus) in Maryland. American Midland Naturalist 110:276-285.

Hoffman D.F. 1979. Coyote-prey relationships in Curlew Valley during a period of low jackrabbit density. Master's thesis, Utah State University, Logan.

Johnson, D.H. 1999. The insignificance of statistical significance testing. Journal of Wildlife Management. 63:763-772.

Jones, J.H., AND N.S. SMith. 1979. Bobcat density and prey selection in central Arizona. Journal of Wildlife Management 43:666-672.

Kearney, T.H., R.H. Peebles, and Collaborators. 1960. Arizona flora. 2nd edition. University of California Press, Berkeley.

LAWRENCE, G.E. 1966. Ecology of vertebrate animals in relation to chaparral fire in the Sierra Nevada foothills. Ecology 47:278-291.

MacCracken, J.G., AND R.M. Hansen. 1987. Coyote feeding strategies in southeastern Idaho: optimal foraging by an opportunistic predator? Journal of Wildlife Management 51:278-285.

Major, J.T., AND J.A. Sherburne. 1988. Interspecific relationships of coyotes, bobcats, and red foxes in western Maine. Journal of Wildlife Management 51:606616.

Mills, L.S., AND F.F. KNowlton. 1991. Coyote space use in relation to prey abundance. Canadian Journal of Zoology 69:1516-1521.

Moore, T.O., L.D. Spence, C.E. Dugnolle, and W.G. HopworTH. 1974. Identification of the dorsal guard hairs of some mammals of Wyoming. Wyoming Game and Fish Department Bulletin 14, Cheyenne.

Murie, O.J. 1954. A field guide to animal tracks. Houghton Mifflen, Boston, MA.

Navaro, A.J., Walker R.S., and M. Suarez. 1995. Dry season food-habits of the gray fox (Urocyon cinereoargenteus fraterculus) in the Belizean Peten. Mammalia 1995:19-24.

NOAA (NATIONAL OCEANIC AND ATMOSPHERIC ADMINISTRATION). 1903-2000. Climatological data: Arizona annual summaries. National Climatic Data Center, Asheville, NC.

Ogen-Odoi, A.A., And T.G. Dilworth. 1984. Effects of grassland burning on the savanna hare-predator relationships in Uganda. African Journal of Ecology 22: 101-106.

Patton, D.R., And J. Gordon. 1995. Fire, habitats, and wildlife. USDA Forest Service Research Report. Flagstaff, AZ.

Pelton, M.R., AND L.C. MarCum. 1975. The potential use of radio-isotopes for determining densities of black bears and other carnivores. Pages 221-236 in R.L. Phillips and C. Jonkel, editors, Proceedings of the 1975 Predator Symposium. Montana Forest Conservation Experimental Station, Missoula. 
Poole, K.G., L.A. Wakelyn, AND P.N. Nicklen. 1996. Habitat selection by lynx in the Northwest Territories. Canadian Journal of Zoology 74:845-850.

Rabinowitz, A. 1990. Notes on the behavior and movements of leopard cats, Felis bengalensis, in a dry tropical forest mosaic in Thailand. Biotropica 22:397-403.

ScotT, T.G. 1955. Dietary patterns of red and gray foxes. Ecology 36:366-367.

Sellers, W.D., AND R.H. Hill. 1974. Arizona climate. University of Arizona Press, Tucson.

STODDART, L.C. 1984. Relative abundance of coyotes, lagomorphs, and rodents on the Idaho National Engineering Laboratory. Annual Report of Predator Ecology and Behavior Project, Denver Wildlife Resource Center.

Swetnam, T.W., and J.L. Betancourt. 1990. Fire-southern oscillation relations in the southwestern United States. Science 249:1017-1020.

Swetnam, T.W., C.D. Allen, and J.L. Betancourt. 1999. Applied historical ecology, using the past to manage for the future. Ecological Applications 9:1189-1206.

Theberge J.B., AND C.H.R. WedELEs. 1989. Prey selection and habitat partitioning in sympatric coyote and red fox populations, southwest Yukon. Canadian Journal of Zoology 67:1285-1290.

Toweill, D.E., AND ANThony R.G. 1988. Coyote foods in a coniferous forest in Oregon. Journal of Wildlife Mangement 52:507-512.
Turkowski, F.J. 1969. Food habits and behavior of the gray fox (Urocyon cinereoargenteus) in the Lower and Upper Sonoran life zones of southwestern United States. Doctoral dissertation, Arizona State University, Tempe.

WEAVER, J.L. 1977. Coyote-food base relationship in Jackson Hole, Wyoming. Doctoral dissertation, Utah State University, Logan.

West, N.E., AND R.W. WeIn. 1971. A plant phenological index technique. BioScience 21:116-117.

Wood, J.E. 1954. Food habits of furbearers of the upland post oak region in Texas. Journal of Mammalogy 35: 406-415.

Wood, J.E., D.E. Davis, AND E.V. Komarek. 1958. The distribution of fox populations in relation to vegetation in southern Georgia. Ecology 39:160-163.

Whitaker, J.O., JR. 1997. National Audubon Society field guide to North American mammals. Alfred A. Knopf, Inc., New York.

ZaR, J.H. 1984. Biostatistical analysis. Prentice Hall, Inc., Englewoods Cliff, NJ.

Zuercher, G.L., P.S. Gipson, and G.C. Stewart. 2003. Identification of carnivore feces by local peoples and molecular analyses. Wildlife Society Bulletin 31:961970 .

Received 29 June 2004 Accepted 3 June 2005 